\title{
OPTIMALISASI PENGGUNAAN MENGGUNAKAN METODE PEMBELAJARAN DOUBLE LOOP PROBLEM SOLVING (DLPS) PADA PEMBELAJARAN EKONOMI DI SMA
}

\author{
Oleh: \\ Firman Aryansyah \\ Dosen Pendidikan Akuntansi FKIP Unversitas Galuh Ciamis Ciamis \\ Jl. R.E. Martadinata No. 150, Ciamis 46274 Jawa Barat \\ Email: firman_aryansyah13@yahoo.com
}

\begin{abstract}
ABSTRAK
Penelitian ini dilatar belakangi bahwa kegiatan belajar mengajar akan tercapai apabila peserta didik mampu mengikuti proses pembelajaran yang diberikan oleh guru di dalam kelas. Penerapan metode pembelajaran sangat menentukan keberhasilan kegiatan belajar dan mengajar, untuk menentukan penerapan metode pembelajaran tergantung guru dalam memilih metode pembelajaran yang baik untuk diterapkan dalam kegiatan belajar dan mengajar. Metode penelitian yang digunakan adalah metode eksperimen. Teknik analisis data yang digunakan dengan uji $N$-Gain dilanjutkan dengan uji hipotesis dan dengan menggunakan uji t-test. Hasil penelitian menunjukan bahwa 1) Terdapat peningkatan hasil belajar peserta didik yang menggunakan metode pembelajaran Double Loop Problem Solving (DLPS) di kelas eksperimen 1 pada mata pelajaran ekonomi SMA. Melalui pengukuran awal (pretest) dan pengukuran akhir (posttest) bernilai 0,848 (kategori tinggi); 2) Terdapat peningkatan hasil belajar peserta didik yang menggunakan metode pembelajaran Creative Problem Solving (CPS) di kelas eksperimen 2 pada mata pelajaran ekonomi SMA. Melalui pengukuran awal (pretest) dan pengukuran akhir (posttest) bernilai 0,786 (kategori tinggi); 3) Terdapat perbedaan yang signifkan antara hasil belajar peserta didik yang menggunakan metode pembelajaran Double Loop Problem Solving (DLPS) dengan hasil belajar peserta didik yang menggunakan Creative Problem Solving (CPS) pada pengukuran akhir (posttest) kelas eksperimen 1 (kelas XI IPS 1) dan kelas eksperimen 2 (kelas XI IPS 2) pada mata pelajaran ekonomi SMA Negeri 3 Ciamis. Hal ini dibuktikan dengan uji hipotesis dan uji t untuk kelas eksperimen di dapat $t_{\text {hitung }}$ dan $t_{\text {tabel }}$ karena $t_{\text {hitung }}>t_{\text {tabel }}$, maka uji hipotesis diterma.
\end{abstract}

Kata Kunci: metode pembelajaran double loop problem solving, hasil belajar.

\section{PENDAHULUAN}

Pendidikan sangat erat kaitannya dengan sekolah, sekolah merupakan penunjang terjadinya kegiatan belajar mengajar. Kegiatan pembelajaran ditentukan oleh peserta didik, seperti yang dikemukakan oleh Dimyati, (2013: 47) bahwa "Belajar merupakan tindakan dan perilaku siswa yang kompleks. Sebagai tindakan, maka belajar hanya dialami oleh siswa sendiri. Siswa adalah penentu terjadinya atau tidak terjadinya proses belajar". Kegiatan belajar mengajar akan tercapai apabila peserta didik mampu mengikuti proses pembelajaran yang diberikan oleh guru di dalam kelas. Tetapi sampai saat ini masih banyak peserta didik yang minat belajarnya kurang, perhatian peserta didik dalam kegiatan pembelajaran kurang, media pembelajaran yang digunakan kurang dan metode pembelajaran yang kurang bervariasi.

Penerapan metode pembelajaran sangat menentukan keberhasilan kegiatan belajar dan mengajar, sehingga penerapan metode pembelajaran sangat diperlukan dalam pembelajaran IPS khususnya ekonomi. Untuk menentukan penerapan metode pembelajaran tergantung guru dalam memilih metode pembelajaran yang baik untuk diterapkan dalam kegiatan belajar dan mengajar.

Kurikulum SMA di Ciamis umumnya sudah menggunakan kurikulum baru yakni kurikulum 2013, sehingga diharapkan peserta didik mampu mengikuti proses pembelajaran yang diberikan oleh guru dan peserta didik mampu mencapai bahkan melampaui nilai KKM (Kriteria Ketuntasan Minimal).

Salah satu metode pembelajaran yang dapat digunakan oleh guru yaitu diantaranya model Problem Solving yang terdiri dari metode Double Loop Problem Solving (DLPS) dan Creative Problem Solving (CPS). Dalam hal ini metode pembelajaran Double Loop Problem Solving (DLPS) menurut Miftahul Huda (2015: 300) yaitu "Pengambilan keputusan menyangkut proses pertimbangan berbagai macam pilihan 
yang akhirnya akan sampai pada suatu kesimpulan atas pilihan yang akan diambilnya". Sedangkan Creative Problem Solving (CPS) menurut Osborn (dalam Miftahul Huda 2015: 298) yaitu "Metode untuk menyelesaikan masalah secara kreatif".

Menurut Shoimin (2014:71) menyatakan bahwa kelebihan metode pembelajaran Double Loop Problem Solving (DLPS), yaitu: 1) Melatih siswa untuk mendesain suatu penemuan; 2) Berpikir dan bertindak kreatif; 3) Memecahkan masalah yang dihadapi secara realistis; 4) Mengidentifikasi dan melakukan penyelidikan; 5) Menafsirkan dan mengevaluasi hasil pengamatan; 6) Merangsang perkembangan kemajuan berpikir siswa untuk menyelesaikan masalah yang dihadapi dengan tepat; 7) Dapat membuat pendidikan sekolah lebih relevan dengan kehidupan, khususnya dunia kerja.

Menurut Shoimin (2014: 57) menyatakan bahwa kelebihan metode pembelajaran Double Loop Problem Solving (DLPS), yaitu: 1) Melatih siswa untuk mendesain suatu penemuan; 2) Berpikir dan bertindak kreatif; 3) Memecahkan masalah yang dihadapi secara realistis; 4) Mengidentifikasi dan melakukan penyelidikan; 5) Menafsirkan dan mengevaluasi hasil pengamatan; 6) Merangsang perkembangan kemajuan berpikir siswa untuk menyelesaikan masalah yang dihadapi dengan tepat; 7) Dapat membuat pendidikan sekolah lebih relevan dengan kehidupan, khususnya dunia kerja.

Jadi, dapat disimpulkan bahwa metode pembelajaran Double Loop Problem Solving (DLPS) dengan metode pembelajaran Creative Problem Solving (CPS) dapat melatih peserta didik dalam berpikir kreatif dalam memecahkan berbagai permasalahan secara realistis, sehingga dengan demikian dapat merangsang cara berpikir peserta didik.

\section{METODE PENELITIAN}

Metode penelitian yang digunakan dalam penelitian ini yaitu metode penelitian eksperimen. Teknik metode penelitian eksperimen yang akan digunakan dalam penelitian ini yaitu Quasi Experimental Design Nonequivalent Control Group Design. Populasi dalam penelitian ini adalah seluruh SMA di Kabupaten Ciamis. Namun, hanya satu sekolah yang dijadikan eksperimen yakni SMAN 3 Ciamis. Siswa kelas XI IPS SMA Negeri 3 Ciamis yang terdiri dari 5 kelas, yaitu XI IPS 1, XI IPS 2, XI IPS 3, XI IPS 4 dan XI IPS 5 yang berjumlah 119 orang peserta didik.
Untuk menentukan kelas eksperimen 1 dan 2 dilakukan secara acak sederhana dengan menggunakan undian setelah dilakukannya pretest terhadap semua populasi. Hasil dari pengundian tersebut yang menjadi sampel penelitian adalah kelas XI IPS 1 dan kelas XI IPS 2. Langkah selanjutnya yaitu melakukan uji homogenitas dengan hasil sebagai berikut, mean atau nilai rata-rata $\mathrm{X}_{1}=38,6$ dan $\mathrm{X}_{2}=38,2$, standar deviasi $S_{1}=10,03$ dan $S_{2}=8,77$, uji $F$ $\left(\mathrm{F}_{\text {hitung }}\right)=1,308$, derajat kebebasan $(\mathrm{dk})$, $\mathrm{dk}_{\text {pembilang }}=24 \mathrm{dan} \mathrm{dk}_{\text {penyebut }}=24, \mathrm{~F}_{\text {tabel }}=1,9804$, sehingga harga $F_{\text {hitung }}$ sebesar 1,308 dan harga $F_{\text {tabel }}$ sebesar 1,984, maka dapat disimpulkan bahwa $F_{\text {hitung }}=1,308<$ dari $F_{\text {tabel }}=1,984$, yang berarti kedua kelas tersebut homogen dan penelitian dapat dilanjutkan. Sehingga penulis menentukan kelas XI IPS 1 dan kelas XI IPS 2 dapat digunakan sebagai objek penelitian. Setelah itu peneliti menentukan kelas XI IPS 1 sebagai kelas eksperimen 1 dan kelas XI IPS 2 sebagai kelas eksperimen 2 .

Adapun teknik analisis data yang digunakan untuk mengetahui peningkatan hasil belajar peserta didik dilakukan dengan menggunakan rumus $N$-Gain, yaitu:

$$
\mathrm{N}-\text { Gain }=\frac{\text { skor posttes }- \text { skor pretest }}{\text { skor maksimum }- \text { skor pretest }}
$$

Sumber: Hake (dalam Susanto, 2012:75)

$\mathrm{N}-$ Gain tersebut diinterpretasikan dengan kriteria sebagai berikut:

Tabel 2

Interpretasi N-Gain

\begin{tabular}{|c|c|}
\hline N-Gain & Kriteria \\
\hline $\mathrm{G}>0,70$ & Tinggi \\
\hline $0,30<\mathrm{G} \leq 0,70$ & Sedang \\
\hline $\mathrm{G}<0,30$ & Rendah \\
\hline
\end{tabular}

Kemudian untuk mengetahui perbedaan hasil belajar peserta didik dengan menggunakan metode pembelajaran Double Loop Problem Solving (DLPS) dan metode pembelajaran Creative Problem Solving (CPS) digunakan rumus uji $\mathrm{t}$ (t-test) dengan taraf signifikan $5 \%$. Berikut ini rumus t-test yang digunakan, yaitu rumus t-test Polled Varian. 


$$
\mathrm{t}=\frac{\overline{\bar{X}}_{1}-\overline{\mathrm{X}}_{2}}{\sqrt{\frac{\left(\mathrm{n}_{1}-1\right) \mathrm{S}_{1}{ }^{2}+\left(\mathrm{n}_{2}-1\right) \mathrm{S}_{2}^{2}}{\mathrm{n}_{1}+\mathrm{n}_{2}-2}\left[\frac{1}{\mathrm{n}_{1}}+\frac{1}{\mathrm{n}_{2}}\right]}}
$$

Sumber: Sugiyono (2015:273)

Adapun hipotesis statistik yang diujikan dalam penelitian ini adalah sebagai berikut:

1. Jika $t_{\text {hitung }}>t_{t a b e l}$, maka hitungan tersebut signifikan, artinya $\mathrm{Ha}$ diterima dan $\mathrm{Ho}$ ditolak atau hipotesis diterima (Ha: $\mu_{1} \neq \mu_{2}$ ). Dapat disimpulkan bahwa terdapat perbedaan yang signifikan antara hasil belajar peserta didik yang menggunakan metode pembelajaran Double Loop Problem Solving (DLPS) dan hasil belajar peserta didik yang menggunakan metode pembelajaran Creative Problem Solving (CPS).

2. Jika $t_{\text {hitung }}<t_{\text {tabel, }}$, maka hitungan tersebut tidak signifikan, artinya Ho diterima atau $\mathrm{Ha}$ ditolak atau hipotesis ditolak (Ho: $\mu_{1}=\mu_{2}$ ). Dapat disimpulkan bahwa tidak terdapat perbedaan yang signifikan antara hasil belajar peserta didik yang menggunakan metode pembelajaran Double Loop Problem Solving (DLPS) dan hasil belajar peserta didik yang menggunakan metode pembelajaran Creative Problem Solving (CPS).

\section{HASIL PENELITIAN DAN PEMBAHASAN}

Untuk mengetahui hasil penelitian tentang hasil belajar peserta didik yang menggunakan metode pembelajaran Double Loop Problem Solving (DLPS yang dilihat dari tabel rekapitulasi hasil belajar peserta didik kelas eksperimen 1.

Tabel 3

Rekapitulasi Hasil Belajar Peserta Didik Kelas Eksperimen 1

\begin{tabular}{|l|l|l|}
\hline Keterangan & Pretest & Posttest \\
\hline Jumlah Sampel & 25 & 25 \\
\hline Nilai Tertinggi & 55 & 100 \\
\hline Nilai Terendah & 15 & 75 \\
\hline Nilai Rata-rata & 38,6 & 90,2 \\
\hline Modus & 40 & 95 \\
\hline
\end{tabular}

Berdasarkan tabel 3 diperoleh data hasil belajar peserta didik pada pengukuran awal (pretest) kelas eksperimen 1 dengan jumlah sampel sebanyak 25 peserta didik, nilai tertinggi sebesar 55 dan nilai terendah 15. Sedangkan untuk nilai rata-ratanya diperoleh sebesar 38,6 dan nilai yang sering muncul (modus) sebesar 40. Kemudian setelah diberi perlakuan dengan menggunakan metode pembelajaran Double Loop Problem Solving (DLPS) pada sampel sebanyak 25 peserta didik, ternyata diperoleh nilai tertinggi sebesar 100 dan nilai terendah sebesar 75. Sedangkan untuk nilai rata-ratanya diperoleh sebesar 90,2 dan nilai yang sering muncul (modus) sebesar 95.

Tabel 4

Kategori $\mathrm{N}$-Gain Kelas Eksperimen 1

\begin{tabular}{|c|c|}
\hline Kategori & Frekuensi $N$-Gain \\
\hline Tinggi & 19 \\
\hline Sedang & 6 \\
\hline Rendah & - \\
\hline Kategori Rata-rata & 0,848 \\
\hline Jumlah Siswa & 25 \\
\hline
\end{tabular}

Berdasarkan Tabel 4 dapat diketahui bahwa jumlah peserta didik yang memiliki kategori $\mathrm{N}$-Gain tinggi berjumlah 19 peserta didik, kategori $N$-Gain sedang berjumlah 6 peserta didik, sedangkan peserta didik yang memiliki kategori $\mathrm{N}$-Gain rendah tidak ada. Sehingga berdasarkan perhitungan $N$-Gain peningkatan hasil belajar peserta didik pada kompetensi dasar menganalisis peran pelaku ekonomi dalam sistem perekonomian Indonesia dengan menggunakan metode pembelajaran Double Loop Problem Solving (DLPS) pada peserta didik kelas XI IPS 1 sebagai kelas eksperimen 1, ternyata setelah melaksanakan pretest dan posstest mendapatkan nilai 0,848 dengan kategori tinggi. Sehingga dapat diketahui bahwa terdapat peningkatan hasil belajar peserta didik pada mata pelajaran ekonomi yang menggunakan metode pembelajaran Double Loop Problem Solving (DLPS) pada kelas eksperimen 1.

Untuk mengetahui peningkatan hasil belajar peserta didik yang menggunakan metode pembelajaran Creative Problem Solving (CPS) yang dilihat dari tabel rekapitulasi hasil belajar peserta didik kelas eksperimen 1. 
Tabel 5

Rekapitulasi Hasil Belajar Peserta Didik Kelas Eksperimen 2

\begin{tabular}{|l|l|l|}
\hline Keterangan & Pretest & Posttest \\
\hline Jumlah Sampel & 25 & 25 \\
\hline Nilai Tertinggi & 50 & 95 \\
\hline Nilai Terendah & 25 & 65 \\
\hline Nilai Rata-rata & 38,2 & 85,4 \\
\hline Modus & 40 & 90 \\
\hline
\end{tabular}

Berdasarkan Tabel 5 diperoleh data hasil belajar peserta didik pada pengukuran awal (pretest) kelas eksperimen 2 dengan jumlah sampel sebanyak 25 peserta didik, nilai tertinggi sebesar 25 dan nilai terendah 50. Sedangkan untuk nilai rata-ratanya diperoleh sebesar 38,2 dan nilai yang sering muncul (modus) sebesar 35. Kemudian setelah diberi perlakuan dengan menggunakan metode pembelajaran Creative Problem Solving (CPS) pada sampel sebanyak 25 peserta didik, ternyata diperoleh nilai tertinggi sebesar 95 dan nilai terendah sebesar 65. Sedangkan untuk nilai rata-ratanya diperoleh sebesar 85,4 dan nilai yang sering muncul (modus) sebesar 90.

Tabel 6

Kategori N-Gain Kelas Eksperimen 2

\begin{tabular}{|c|c|}
\hline Kategori & Frekuensi $N$-Gain \\
\hline Tinggi & 15 \\
\hline Sedang & 10 \\
\hline Rendah & - \\
\hline Kategori Rata-rata & 0,786 \\
\hline Jumlah Siswa & 25 \\
\hline
\end{tabular}

Bersadasrkan Tabel 6 dapat diketahui bahwa jumlah peserta didik yang memiliki kategori $N$-Gain tinggi berjumlah 15 peserta didik, kategori $\mathrm{N}$-Gain sedang berjumlah 10 peserta didik, sedangkan peserta didik yang memiliki kategori $\mathrm{N}$-Gain rendah tidak ada. Sehingga berdasarkan perhitungan $N$-Gain peningkatan hasil belajar peserta didik pada kompetensi dasar menganalisis peran pelaku ekonomi dalam sistem perekonomian Indonesia dengan menggunakan metode pembelajaran Creative Problem Solving (CPS) pada peserta didik kelas eksperimen 2, ternyata setelah melaksanakan pretest dan posstest mendapatkan nilai 0,786 dengan kategori tinggi. Sehingga dapat diketahui bahwa terdapat peningkatan hasil belajar peserta didik pada mata pelajaran ekonomi yang menggunakan metode pembelajaran Creative Problem Solving (CPS) pada kelas eksperimen 2.

Untuk mengetahui perbedaan hasil belajar peserta didik yang menggunakan metode pembelajaran Double Loop Problem Solving (DLPS) dengan metode pembelajaran Creative Problem Solving (CPS), maka perhitungan yang digunakan adalah uji t-test. Uji t-test dalam penelitian ini adalah dengan membandingkan rata-rata hasil posttest kelas eksperimen 1 dengan hasil posttest kelas eksperimen 2, dengan hasil begarai berikut; mean $X_{1}=90,2$ dan $X_{2}=$ 85,4 , standar deviasi $S_{1}=8,48$ dan $S_{2}=8,15$, $\mathrm{t}_{\text {hitung }}=2,0425$, derajat kebebasan $(\mathrm{dk})=48, \mathrm{t}_{\text {tabel }}$ $=2,0126$. Berdasarkan nilai $t_{\text {hitung }}$ yaitu 2,0425 dan $t_{\text {tabel }} 2,0126$, maka nilai $t_{\text {hitung }}$ lebih besar dari nilai $t_{\text {tabel. }}$ Hal ini menunjukan bahwa terdapat perbedaan hasil belajar peserta didik yang menggunakan metode pembelajaran Double Loop Problem Solving (DLPS) dan hasil belajar peserta didik yang menggunakan metode pembelajaran Creative Problem Solving (CPS).

Tabel 7

Hasil Perhitungan t-test Uji Dua Pihak

\begin{tabular}{|l|l|l|l|l|l|}
\hline Kelas & $\begin{array}{l}\text { Standar } \\
\text { Deviasi }\end{array}$ & $\mathrm{dk}$ & $\alpha$ & $\mathrm{t}_{\text {hitung }}$ & $\mathrm{t}_{\text {tabel }}$ \\
\hline $\begin{array}{l}\text { Eksperimen } \\
1 \text { (XI IPS 1) }\end{array}$ & 8,48 & 48 & & & \\
\hline $\begin{array}{l}\text { Eksperimen } \\
\text { 2(XI IPS 2) }\end{array}$ & 8,15 & 48 & 0,05 & 2,0425 & 2,0126 \\
\hline
\end{tabular}

Berdasarkan tabel tersebut, dapat diketahui bahwa $t_{\text {hitung }}>t_{\text {tabel }}(2,0425>2,0126)$. Hal tersebut menunjukan bahwa hipotesis diterima, artinya terdapat perbedaan yang signifikan hasil belajar peserta didik yang menggunakan metode pembelajaran Double Loop Problem Solving (DLPS) dengan hasil belajar peserta didik yang menggunakan metode pembelajaran Creative Problem Solving (CPS).

Hasil belajar peserta didik yang menggunakan metode pembelajaran Double Loop Problem Solving (DLPS) memiliki nilai rata-rata posttest sebesar 90,2 dan hasil belajar peserta didik yang menggunakan metode pembelajaran Creative Problem Solving (CPS) memiliki nilai rata-rata posttest sebesar 85,4. Artinya terdapat perbedaan hasil belajar peserta didik yang menggunakan metode pembelajaran Double Loop Problem Solving (DLPS) dengan hasil belajar peserta didik yang menggunakan metode pembelajaran Creative Problem Solving (CPS). 
Metode pembelajaran Double Loop Problem Solving (DLPS) menekankan kepada peserta didik untuk dapat bekerja secara berkelompok dalam menyelesaikan suatu permasalahan dengan saling mengemukakan pendapat yang ada di pikirannya, dan dengan menggunakan metode pembelajaran Double Loop Problem Solving (DLPS) dapat melatih peserta didik untuk berpikir kreatif dan peserta didik dapat saling menghargai pendapat peserta didik yang lain. Sehingga peningkatan hasil belajar peserta didik dapat terlihat pada pengukuran awal (pretest) dan pengukuran akhir (posttest), hal ini disebabkan karena metode pembelajaran Double Loop Problem Solving (DLPS) ini yang lebih ditekankan adalah peserta didik untuk lebih aktif dan kreatif di dalam proses pembelajaran. Maka dari itu peserta didik dapat lebih mudah menyelesaikan suatu permasalahan yang diberikan oleh guru dengan dituntut setiap peserta didik harus mengemukakan pendapatnya masing-masing, dan peserta didik yang kurang aktif akan mendapat paksaan oleh keadaan untuk mengemukakan pendapatnya, sehingga akan lebih melatih keberanian peserta didik untuk mengemukakan pendapatnya dan peserta didik yang lainnya harus menghargai pendapat peserta didik yang lainnya.

Metode pembelajaran Creative Problem Solving (CPS) dapat meningkatkan hasil belajar peserta didik, karena metode pembelajaran Creative Problem Solving (CPS) dapat membuat peserta didik untuk memperluas proses berpikirnya, sehingga peserta didik menjadi lebih berpikir kreatif dan dapat mengikuti proses pembelajaran. Untuk peserta didik yang kurang aktif akan termotivasi dan memberanikan diri untuk mengemukakan pendapatnya karena metode pembelajaran Creative Problem Solving (CPS) peserta didik dituntut untuk mengemukakan pendapatnya masing-masing, sehingga untuk peserta didik yang kurang aktif akan lebih termotivasi karena seolah-olah terpaksa oleh situasi.

Penerapan kedua metode pembelajaran ini melibatkan peserta didik untuk bekerja sama/berkelompok dan peserta didik dilibatkan untuk berpikir dan bertindak secara kreatif dalam proses pembelajaran. Tetapi terdapat perbedaan karena pada kelas eksperimen 1 (kelas XI IPS 1) menggunakan metode pembelajaran Double Loop Problem Solving (DLPS), dimana di dalam metode pembelajaran Double Loop Problem Solving (DLPS) ini peserta didik dituntut memiliki keterampilan untuk mengelola pemikirannya, sehingga peserta didik mampu memecahkan masalah maupun pengambilan keputusan, karena metode pembelajaran Double Loop Problem Solving (DLPS) ini mempunyai 2 solusi yaitu solusi sementara dan solusi langsung, kemudian peserta didik harus mengidentifikasi dulu permasalahannya untuk menentukan solusi mana yang dapat memecahkan masalah tersebut. Sehingga peserta didik dipaksa untuk berpikir dan peserta didik menjadi lebih antusias untuk bisa menyelesaikan masalah dengan solusi yang tepat. Sedangkan pada kelas eksperimen 2 (kelas XI IPS 2) menggunakan metode pembelajaran Creative Problem Solving (CPS) peserta didik dituntut untuk bekerja sama/berkelompok dan peserta didik sama dilibatkan untuk mempunyai keterampilan memecahkan masalah memperluas proses berpikir. Tetapi hal tersebut tdak membuat peserta didik terampil dalam mengerjakan atau menyelesaikan suatu permasalahan, dan setiap peserta didik di dalam kelompoknya lebih mengandalkan yang pintar untuk memecahkan masalah.

Dengan demikian penerapan metode pembelajaran Double Loop Problem Solving (DLPS) dengan metode pembelajaran Creative Problem Solving (CPS), keduanya memiliki peran yang baik di dalam meingkatkan hasil belajar peserta didik, tetapi hasil belajar peserta didik yang menggunakan metode pembelajaran Double Loop Problem Solving (DLPS) lebih tinggi dibandingkan dengan yang menggunakan metode pembelajaran Creative Problem Solving (CPS).

\section{PENUTUP \\ Simpulan}

Berdasarkan hasil penelitian dan pembahasan di atas, dapat disimpulkan bahwa terdapat peningkatan hasil belajar peserta didik, baik yang menggunakan metode pembelajaran Double Loop Problem Solving (DLPS) di kelas eksperimen 1 (XI IPS 1) maupun yang menggunakan metode pembelajaran Creative Problem Solving (CPS) di kelas eksperimen 2 (XI IPS 2) SMA Negeri 3 Ciamis sebagai sampel SMA se Kabupaten Ciamis pada mata pelajaran ekonomi melalui pengukuran awal (pretest) dan pengukuran akhir (posttest). Walaupun hasil belajar peserta didik yang menggunakan metode pembelajaran Double Loop Problem Solving (DLPS) mengalami peningkatan yang lebih tinggi dibandingkan dengan yang menggunakan 
metode pembelajaran Creative Problem Solving (CPS). Kemudian hasil penelitian menunjukan adanya perbedaan yang signifikan antara hasil belajar peserta didik yang menggunakan metode pembelajaran Double Loop Problem Solving (DLPS) dengan hasil belajar peserta didik yang menggunakan Creative Problem Solving (CPS) pada pengukuran akhir (posttest) kelas eksperimen 1 (kelas XI IPS 1) dan kelas eksperimen 2 (kelas XI IPS 2) pada mata pelajaran ekonomi SMA Negeri 3 Ciamis.

\section{DAFTAR PUSTAKA}

Dimyati. 2013. Belajar dan Pembelajaran. Jakarta: PT Rineka Cipta

Huda, Miftahul. 2015. Model-Model Pengajaran dan Pembelajaran: Isu-Isu Metodis dan Paragmatis. Yogyakarta: Pustaka Belajar

Shoimin, Aris, 2014. 68 Model Pembelajaran Inovatif dalam Kurikulum 2013. Yogyakarta: Ar-Ruzz Media

Sugiyono. 2015. Metode Penelitian Pendidikan Pendekatan Kuantitatif, Kualitatif, dan $R \& D$. Bandung: Alfabeta

Susanto, Joko. 2012. Pengembangan Perangkat Pembelajaran Berbasis Lesson Study dengan Kooperatif Tipe Numbered Head Together untuk Meningkatkan Aktivitas dan Hasil Belajar IPA di SD. Jurnal Pendidikan Primer. (Volume 02). 